Full length article

\title{
Effects of ocean acidification on immune responses of the Pacific oyster Crassostrea gigas
}

\author{
Qing Wang ${ }^{\mathrm{a}, 1}$, Ruiwen Cao ${ }^{\mathrm{a}, \mathrm{d}, 1}$, Xuanxuan Ning ${ }^{\mathrm{b}}$, Liping You ${ }^{\mathrm{a}}$, Changkao $\mathrm{Mu}^{\mathrm{c}}$, \\ Chunlin Wang ${ }^{c}$, Lei Wei ${ }^{a}$, Ming Cong ${ }^{a}$, Huifeng Wu ${ }^{\text {, }}$, Jianmin Zhao ${ }^{\text {a, }}$ * \\ ${ }^{a}$ Key Laboratory of Coastal Environmental Processes and Ecological Remediation, CAS, Shandong Provincial Key Laboratory of Coastal Zone Environmental \\ Processes, Yantai Institute of Coastal Zone Research, Chinese Academy of Sciences, Yantai, 264003, PR China \\ ${ }^{\mathrm{b}}$ Yantai Oceanic Environmental Monitoring Central Station of SOA, Yantai, 264006, PR China \\ ${ }^{c}$ Key Laboratory of Applied Marine Biotechnology, Ministry of Education, Faculty of Life Science and Biotechnology, Ningbo University, Ningbo, 315211, PR \\ China \\ ${ }^{\mathrm{d}}$ University of Chinese Academy of Sciences, Beijing, 100049, PR China
}

\section{A R T I C L E I N F O}

\section{Article history:}

Received 27 May 2015

Received in revised form

11 December 2015

Accepted 14 December 2015

Available online 17 December 2015

\section{Keywords:}

Ocean acidification

$\mathrm{pCO}_{2}$

Oyster

Immune response

Antioxidant enzyme

\begin{abstract}
A B S T R A C T
Ocean acidification (OA), caused by anthropogenic $\mathrm{CO}_{2}$ emissions, has been proposed as one of the greatest threats in marine ecosystems. A growing body of evidence shows that ocean acidification can impact development, survival, growth and physiology of marine calcifiers. In this study, the immune responses of the Pacific oyster Crassostrea gigas were investigated after elevated $\mathrm{pCO}_{2}$ exposure for 28 days. The results demonstrated that $\mathrm{OA}$ caused an increase of apoptosis and reactive oxygen species (ROS) production in hemocytes. Moreover, elevated $\mathrm{pCO}_{2}$ had an inhibitory effect on some antioxidant enzyme activities and decreased the GSH level in digestive gland. However, the mRNA expression pattern of several immune related genes varied depending on the exposure time and tissues. After exposure to $\mathrm{pCO}_{2}$ at $2000 \mathrm{ppm}$ for 28 days, the mRNA expressions of almost all tested genes were significantly suppressed in gills and stimulated in hemocytes. Above all, our study demonstrated that elevated $p \mathrm{CO}_{2}$ have a significant impact on the immune systems of the Pacific oyster, which may constitute as a potential threat to increased susceptibility of bivalves to diseases.
\end{abstract}

(C) 2015 Elsevier Ltd. All rights reserved.

\section{Introduction}

Rising atmospheric $\mathrm{CO}_{2}$ has become one of the most critical environmental problems with the development of industries. About $30 \%$ of the atmospheric carbon dioxide has diffused into the ocean through the direct chemical exchange [1]. The absorption of $\mathrm{CO}_{2}$ by the seawater results in a net increase in protons $\left(\mathrm{H}^{+}\right)$and a reduction in $\mathrm{pH}$, which finally leads to ocean acidification (OA). Presently, the atmospheric global average level of $\mathrm{CO}_{2}$ has reached $400 \mathrm{ppm}$, and is predicted to increase to $500-1000 \mathrm{ppm}$ by the end of this century $[2,3]$. It is estimated that the $\mathrm{pH}$ of oceanic surface waters will decrease by $0.14-0.35 \mathrm{pH}$ units by the year $2100[2,4]$. OA may have profound and diverse consequences for marine

\footnotetext{
* Corresponding author.

E-mail address: jmzhao@yic.ac.cn (J. Zhao).

1 These authors contribute equally to this article.
}

biodiversity and ecosystem functioning [5,6], and poses a serious threat to marine organisms, especially calcifying organisms such as coral, sea urchin and mollusk [7].

Over the past 10 years, accumulating evidence suggests that $\mathrm{OA}$ could result in delayed embryonic development [8,9], decreased larval growth $[10,11]$ and increased mortality [12] of many marine mollusks. Moreover, OA stress has also been found to affect many physiological processes, such as calcification [13], energy metabolism [14] and behavior [15,16] of calcifying organisms. However, there is a lack of studies on the effects of OA on other vital processes of marine organisms such as immune and stress responses [17]. To date, only few studies have investigated the impacts of OA stress on immune systems in bivalve, echinoderm and crustacean [18-21], which have highlighted the potential negative effect of reduced seawater $\mathrm{pH}$ on the host defense responses of marine invertebrates.

The Pacific oyster Crassostrea gigas (Thunberg, 1793) is one of the most important fishery and aquaculture species, which is widely used as animal model for studying the adaptive mechanism to 
coastal environment changes [22]. Previous studies have found that OA stress impaired the energy metabolic pathways in oysters, and also retarded the normal growth and development $[23,24]$. However, the impact of OA on the immune responses of oysters has received little attention so far. In order to understand how the oyster modulates its immune capacity to cope with OA stress, the immune and defensive responses of oyster $C$. gigas from the Yellow Sea (China) were investigated after short-term exposure (4 weeks) to $\mathrm{CO}_{2}$-acidified seawater, hopefully shedding light on the understanding of the potential implications of $\mathrm{OA}$ for invertebrate immunological function.

\section{Materials and methods}

\subsection{Animals and experimental design}

Adult Pacific oysters, $C$. gigas, with a shell length of $5-7 \mathrm{~cm}$, were purchased from a local shellfish farm, and acclimated for 2 weeks at $17{ }^{\circ} \mathrm{C}$ and $31 \%$ salinity. During the acclimation period, the oysters were fed three times daily with a commercial algal blend containing the Chlorella vulgaris Beij and Phaeodactylum tricornutum at a concentration of $1 \times 10^{4}$ cells $\mathrm{ml}^{-1}$.

After the acclimation period, oysters were cultured in seawater continuously bubbled with the ambient air or air $-\mathrm{CO}_{2}$ mixture. Three $\mathrm{CO}_{2}$ levels were used that were representative of the presentday condition and atmospheric $\mathrm{CO}_{2}$ concentrations predicted for the years $2100\left(\sim p \mathrm{CO}_{2} 1000 \mu \mathrm{atm}\right)$ and $2250\left(\sim p \mathrm{CO}_{2} 2000 \mu \mathrm{atm}\right)$. A total of 180 oysters were randomly divided into nine assigned tanks (30L) with three replicates per treatment. For elevated $p \mathrm{CO}_{2}$ treatments, the target $p \mathrm{CO}_{2}$ levels were achieved through air and $\mathrm{CO}_{2}$ gas flow adjustment system (Qingdao AKB Instrument \& Equipment Co. Ltd). For the control group, the ambient air was bubbled into experimental containers. Seawater was changed every other day using pre-bubbled seawater which had been equilibrated previously following the methodology described above.

$\mathrm{pH}$ was measured daily with a $\mathrm{pH}$ electrode ( $\mathrm{pH}$ meter $\mathrm{PB}-10$, Sartorius Instruments, Germany) calibrated with National Institute of Standards and Technology standard pH solutions (NIST, USA). Other water parameters (temperature, salinity, total dissolved inorganic carbon) were determined every other day. Total alkalinity (TA) were measured weekly with the method of Haraldsson et al. [25]. Seawater carbonate chemistry parameters (Table 1 ) were estimated according to the known values of $\mathrm{pH}$ and TA levels using the software CO2SYS [26]. For CO2SYS settings, seawater $\mathrm{pH}$ constants used the NIST scale from Millero et al. [27], and the $\mathrm{KSO}_{4}{ }^{-}$constant was set from Dickson et al. [28] and refitted by Lewis and Wallace [26]. The information of the relevant water chemistry parameters is summarized in Table 1.

After exposure of 7, 14 and 28 days, hemolymph of 6

Table 1

Measured and calculated seawater chemistry parameters during the experimental exposures. The $\mathrm{pH}$ was monitored daily with a $\mathrm{pH}$ electrode calibrated with NBS Standard $\mathrm{pH}$ solutions, and total alkalinity (TA) was determined weekly. $p \mathrm{CO}_{2}$, total dissolved inorganic carbon (DIC) and $\Omega$ calcite were calculated using CO2SYS software.

\begin{tabular}{lccc}
\hline Parameters & Control & \multicolumn{2}{c}{ Elevated $p \mathrm{CO}_{2}$ exposure } \\
\cline { 3 - 4 } & & $\sim 1000 \mathrm{ppm}$ & $\sim 2000 \mathrm{ppm}$ \\
\hline Temperature $\left({ }^{\circ} \mathrm{C}\right)$ & $17.4 \pm 0.2$ & $17.5 \pm 0.5$ & $17.4 \pm 0.3$ \\
Salinity $(\%)$ & $31.2 \pm 0.5$ & $31.3 \pm 0.5$ & $31.2 \pm 0.5$ \\
$\mathrm{pH}(\mathrm{NBS} \mathrm{scale})$ & $8.17 \pm 0.02$ & $7.80 \pm 0.02$ & $7.55 \pm 0.02$ \\
$\mathrm{TA}(\mu \mathrm{mol} / \mathrm{kg})$ & $2385.4 \pm 33.88$ & $2367.2 \pm 49.07$ & $2369.2 \pm 13.09$ \\
$p \mathrm{CO}_{2}(\mathrm{ppm})$ & $438.80 \pm 28.11$ & $1126.66 \pm 43.79$ & $2062.06 \pm 94.69$ \\
$\mathrm{DIC}(\mu \mathrm{mol} / \mathrm{kg})$ & $2170.54 \pm 12.19$ & $2298.82 \pm 5.09$ & $2379.21 \pm 5.96$ \\
$\Omega$ calcite & $3.98 \pm 0.19$ & $1.86 \pm 0.06$ & $1.09 \pm 0.04$ \\
\hline
\end{tabular}

individuals in each treatment was withdrawn using a $2 \mathrm{ml}$ syringe equipped with a $22 \mathrm{G}$ needle from the pericardial cavity. $1.5 \mathrm{ml}$ of hemolymph was collected from each individual and filtered through an $80 \mu \mathrm{m}$ mesh to eliminate debris. After that, the hemolymph samples were maintained on ice to prevent spontaneous aggregation, and then subjected to the measurement of phagocytic activity and reactive oxygen species (ROS) production. Meanwhile, additional $0.5 \mathrm{ml}$ of hemolymph was withdrawn and centrifuged to collect hemocytes which were used for RNA extraction. In addition, oysters of both control and OA-treated groups were immediately dissected for gills and hepatopancreas, respectively. All the tissues were flash frozen in liquid nitrogen, and stored at $-80{ }^{\circ} \mathrm{C}$ prior to RNA extraction and antioxidant enzymes assay.

\subsection{Phagocytic capacities}

Phagocytosis was measured by ingestion of fluorescent beads through an in vitro assay. Briefly, $500 \mu \mathrm{L}$ of hemolymph were incubated with $50 \mu \mathrm{l}$ of a $1 / 10$ dilution of fluorescent latex beads (2.0 $\mu \mathrm{m}$ in diameter, Polysciences Inc.) for $1 \mathrm{~h}$ in the dark at ambient temperature. Then the hemocytes were analyzed on the FL1 detector of the flow cytometry (FACSCalibur, BD Biosciences), and phagocytic activity was estimated by the percentage of hemocytes that had ingested three or more beads.

\subsection{Reactive oxygen species (ROS) production}

The non-induced reactive oxygen species (ROS) production was measured using 2'7'-dichlorofluorescein diacetate (DCFH-DA; Molecular Probes, Invitrogen). Oxidation of non-fluorescent DCFH-DA to fluorescent product DCFH was used to quantify the production of reactive oxygen species (ROS) by hemocytes.5 $\mu \mathrm{L}$ of DCFH-DA working solution was added to $500 \mu \mathrm{l}$ of the hemolymph to yield a final concentration of $10 \mu \mathrm{M}$. The mixtures were then incubated in the dark at ambient temperature for 15 min prior to flow cytometry analysis.

\subsection{Apoptosis detection}

The apoptosis of hemocytes was detected using the Annexin V-FITC Apoptosis Detection Kit (BioVision, USA) according to the manufacturer's recommendations. Briefly, the hemocytes were washed twice with PBS and re-suspended using $1 \times$ Annexin V Binding Buffer at $2-3 \times 10^{6}$ cells $/ \mathrm{mL}$. Then, $5 \mu \mathrm{l}$ of Annexin V-FITC and $10 \mu \mathrm{l}$ of Propidium Iodide (PI) Buffer were added to each tube with $100 \mu \mathrm{l}$ of hemocyte suspension. Next, $400 \mu \mathrm{l} 1 \times$ Annexin-V Binding Buffer was added to each tube. Finally, the hemocytes were incubated at room temperature for $15 \mathrm{~min}$ in the dark and then analyzed by flow cytometry for fluorescence in the FL-1 (Annexin V) and FL-2 (PI) channels [29].

\subsection{Quantitative real-time PCR analysis}

Total RNA from the tissues of hemocytes, gills and hepatopancreas was extracted using Trizol reagent following the manufacturer's instructions (Invitrogen), respectively. The first-strand cDNA was synthesized according to M-MLV RT Usage information (Promega) using oligo (dT)-adaptor as primer and the DNase Itreated total RNA as template. Expression of selected immune responsive genes was measured in an Applied Biosystems 7500 Real-Time PCR System. Gene-specific primers for heat shock protein 70 (Hsp70, AAD31042.1), heat shock protein 90 (Hsp90, ABS18268.1), extracellular $\mathrm{Cu}-\mathrm{Zn}$ superoxide dismutase (SOD, EKC39002.1), glutathione peroxidase (GPX, selenium-dependent 
Table 2

Primers used in this study.

\begin{tabular}{lll}
\hline Gene name & Forward primer $\left(5^{\prime}-3^{\prime}\right)$ & Reverse primer $\left(5^{\prime}-3^{\prime}\right)$ \\
\hline Def & GCTGGATTTGGTGTCC & ACAGTAGCCCGCTCTACAAC \\
Prp & CCACCATGTTCTCTCGGAGG & CTTGTAGAACGGGCTAGCAC \\
BPI & GATAGAAATAGGAATGGACGG & GTTATAGATCCACGCTGCTCC \\
SOD & AGAGGTGAATGCTACCAGG & AGGCCAAGAATTCCGTCTG \\
GPx & GACCGTGGAACCAATGGACATC & GTTGGATTCGGACACAGATAGGG \\
Hsp70 & GCATGTGAGCGAGCAAAACG & TGGCAGCTTGAACAGCAGC \\
Hsp90 & GGTGAATGTTACCAAGGAAGG & GTTACGATACAGCAAGGAGATG \\
18S rRNA & TCCCAGTAAGCGCGAGTCAT & ACGGGCGGTGTGTACAAAG \\
\hline
\end{tabular}

glutathione peroxidase, ABS19600.1), bacterial/permeabilityincreasing protein (BPI, AAN84552.1), defensin (Def, ACQ76287.1), proline rich peptide (Prp, ACQ72987.1) were shown in Table 2. 18S rRNA (AB064942) was used as internal control to verify the successful transcription and to calibrate the cDNA template. The real-time quantitative PCR amplifications were carried out in triplicate in a total volume of $50 \mu \mathrm{l}$ containing $25 \mu \mathrm{l}$ of $2 \times$ SYBR Premix Ex TaqTM(TaKaRa), $1.0 \mu$ of $50 \times$ ROX Reference DYE, $16.0 \mu \mathrm{l}$ DEPC-treated $\mathrm{H}_{2} \mathrm{O}, 1.0 \mu \mathrm{l}$ of each primer, $6.0 \mu \mathrm{l}$ of $1: 20$ diluted cDNA. All real-time PCR assays were run using the following program: $50{ }^{\circ} \mathrm{C}$ for $2 \mathrm{~min}$ and $95^{\circ} \mathrm{C}$ for $10 \mathrm{~min}$, followed by 40 cycles of $94{ }^{\circ} \mathrm{C}$ for $15 \mathrm{~s}, 58{ }^{\circ} \mathrm{C}$ for $45 \mathrm{~s}, 72{ }^{\circ} \mathrm{C}$ for $30 \mathrm{~s}$. Dissociation curve analysis of amplicons was performed at the end of each PCR to confirm that only one PCR product was amplified and detected. After the PCR program, data were analyzed with the ABI 7500 SDS software. To maintain consistency, the baseline was set automatically by the software. The comparative $C_{T}$ method $\left(2^{-\Delta \Delta C T}\right.$ method) was used to analyze the expression level of the immune responsive genes [30].

\subsection{Antioxidant enzymes activities and lipid peroxidation}

The tissues of gills and hepatopancreas $(\sim 50 \mathrm{mg})$ were homogenized ( $1: 10 \mathrm{w}: \mathrm{v})$ in an ice-cold lysis buffer $(50 \mathrm{mM}$ Tris- $\mathrm{HCl}, \mathrm{pH}$ 7.5 ), respectively. The homogenate was centrifuged at $10,000 \times g$ for $30 \mathrm{~min}$, and the resultant supernatant was subjected to the measurement of antioxidant enzymes activities.

The antioxidant enzymes, including superoxide dismutase (SOD, EC 1.15.1.1), glutathione S-transferases (GST, EC 2.5.1.18), catalase (CAT, EC 1.11.1.6), and glutathione peroxidase (GPx, EC 1.11.1.9) were assayed using commercial activity-based kits (Jiancheng, Nanjing, China). Lipid peroxidation was quantified by measuring the thiobarbituric acid reactive substances (TBARS) produced during lipid peroxidation, and expressed in terms of malondialdehyde (MDA) content. The total protein concentration in the supernatant was measured using the BCA assay kit (Pierce, Rockford, IL, USA) to normalize the data of enzyme activities. The antioxidant enzymes activities and MDA content were expressed as $\mathrm{U} \mathrm{mg}^{-1}$ protein and nmol $\mathrm{mg}^{-1}$ protein, respectively. Total glutathione (GSH) content was determined using the DTNB-GSSG Reductase Recycling Assay [31]. Sample concentration was determined by comparison with the predetermined glutathione standard curve, and expressed as $\mathrm{mg} / \mathrm{g}$ protein.

\subsection{Statistical analysis}

All experimental data were analyzed as mean \pm standard deviation with at least four replicates. One-way analysis of variance (one-way ANOVA) was performed on all data using SPSS 16.0 statistical software, and Duncan test was used for posthoc test and the significance level was set as $p<0.05$.
A

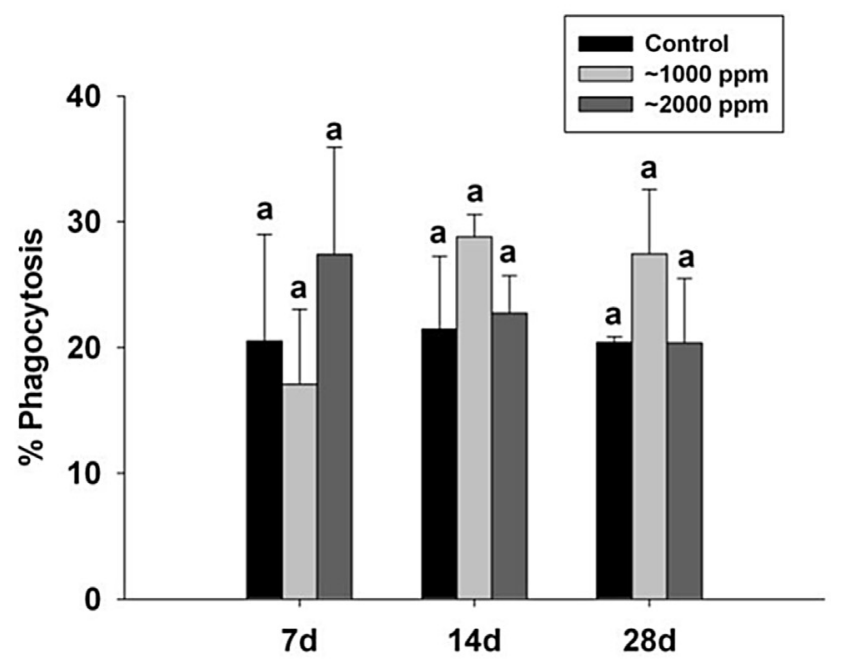

B

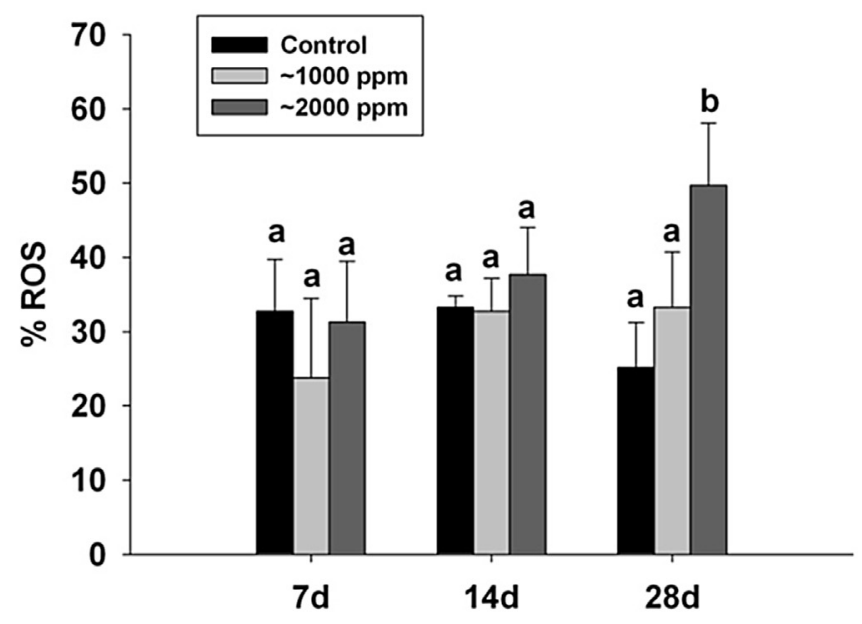

C

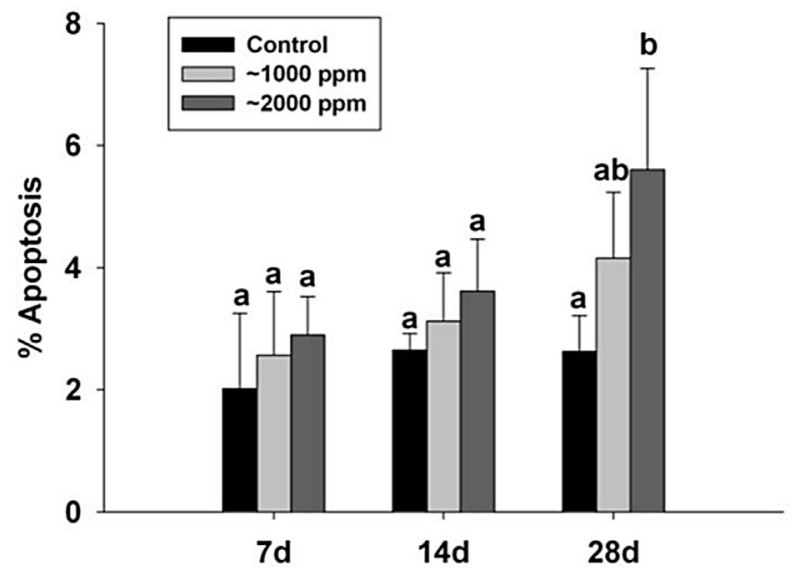

Fig. 1. Temporal changes of phagocytosis, respiratory burst (release of ROS) and apoptosis in the hemocytes of oysters post elevated $\mathrm{pCO}_{2}$ exposure. Each bar represented mean \pm S.D. $(n>4)$. Differing letters indicate significant differences among treatments at the same exposure time $(p<0.05)$; identical letters indicate no significant difference. 
A
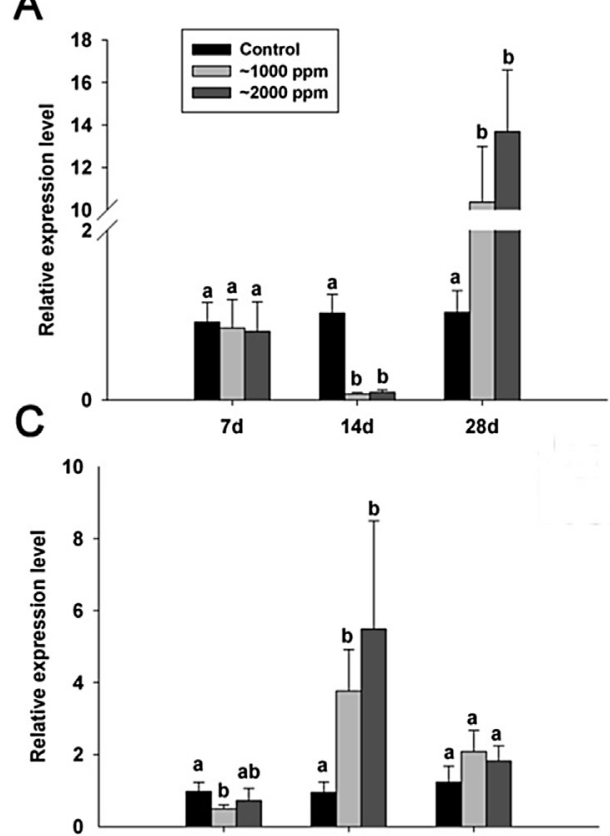

E

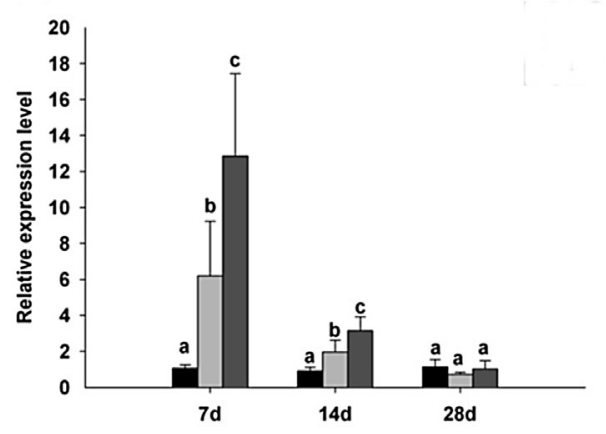

G

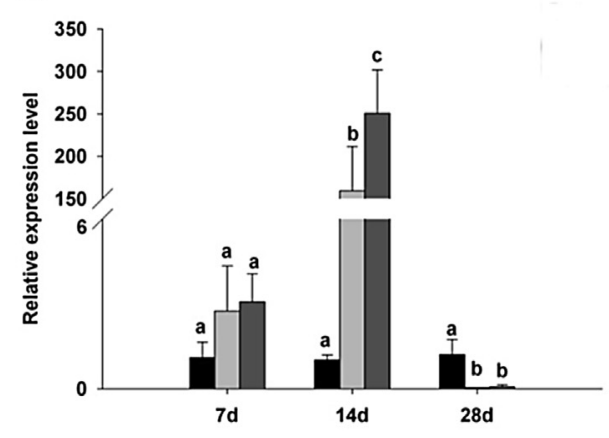

B
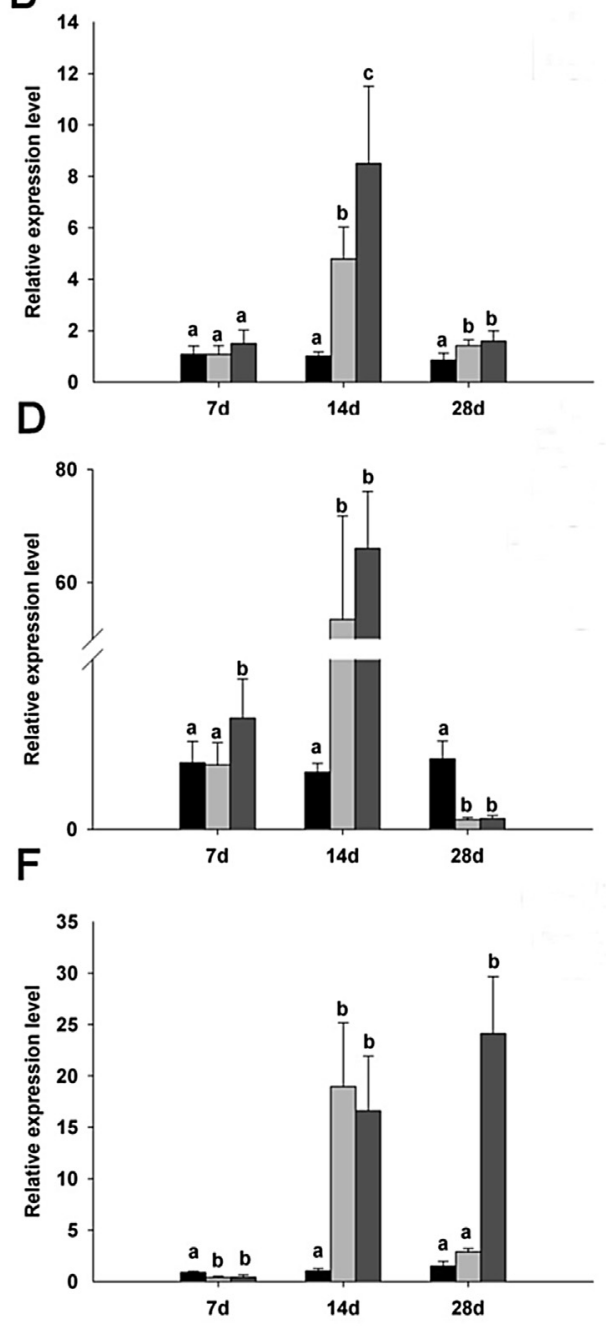

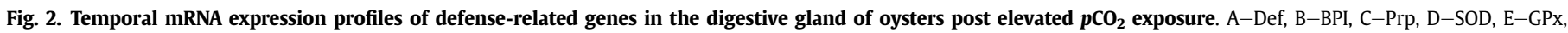

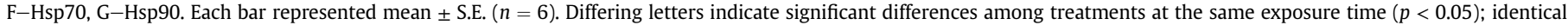
letters indicate no significant difference.

\section{Results}

\subsection{Effects of $O A$ on phagocytosis, respiratory burst and apoptosis of hemocytes}

After exposure to elevated $\mathrm{pCO}_{2}$, no significant change in the phagocytic activity of hemocytes was observed between all treatments. Similarly, there was no significant impact on respiratory burst and apoptosis of hemocytes after the oysters exposed to elevated $p \mathrm{CO}_{2}$ for 7 days and 14 days. However, higher level $p \mathrm{CO}_{2}$ exposure $(\sim 2000 \mathrm{ppm})$ stimulated respiratory burst and apoptosis in hemocytes significantly on Day 28 ( $p<0.05$ ) (Fig. 1).

\subsection{Effects of OA on MRNA expression of immune-related genes in digestive gland, gills and hemocytes}

In oyster digestive gland, the mRNA expression of Def (Fig. 2A), BPI (Fig. 2B) and Hsp90 (Fig. 2G) did not change significantly after 
A

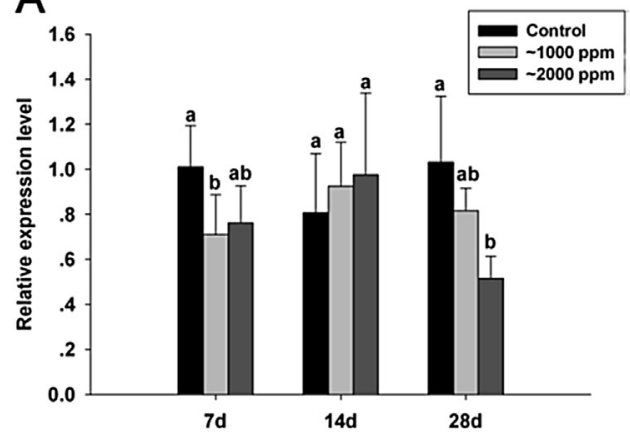

C

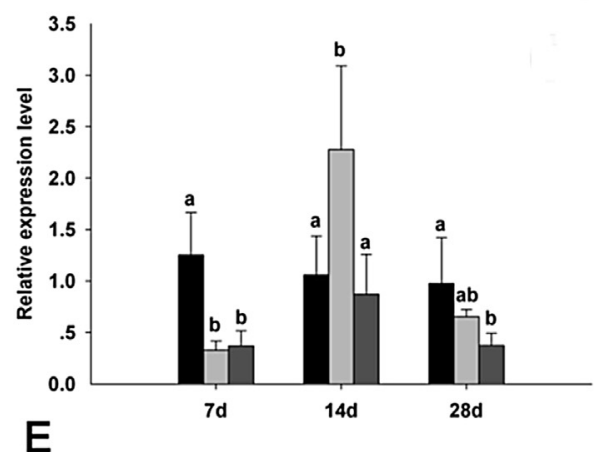

E
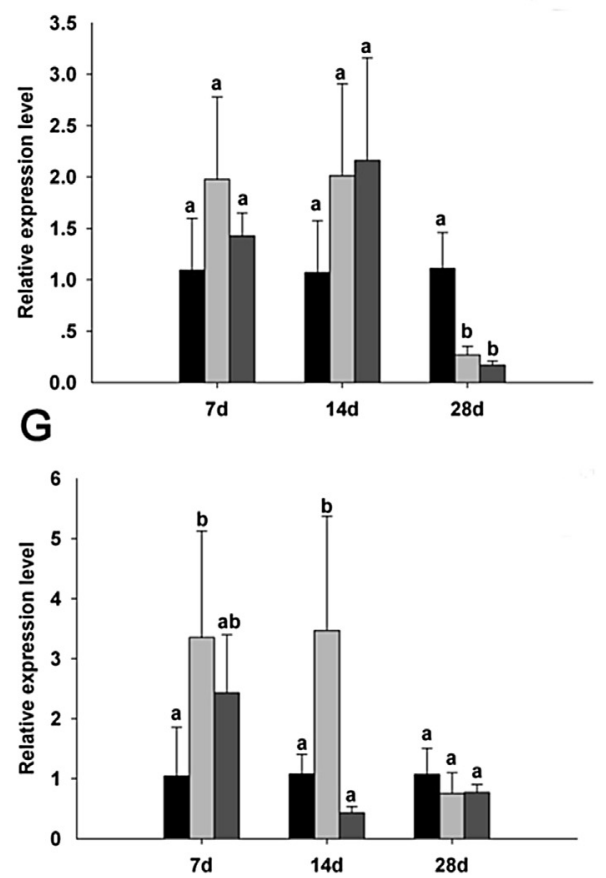

B
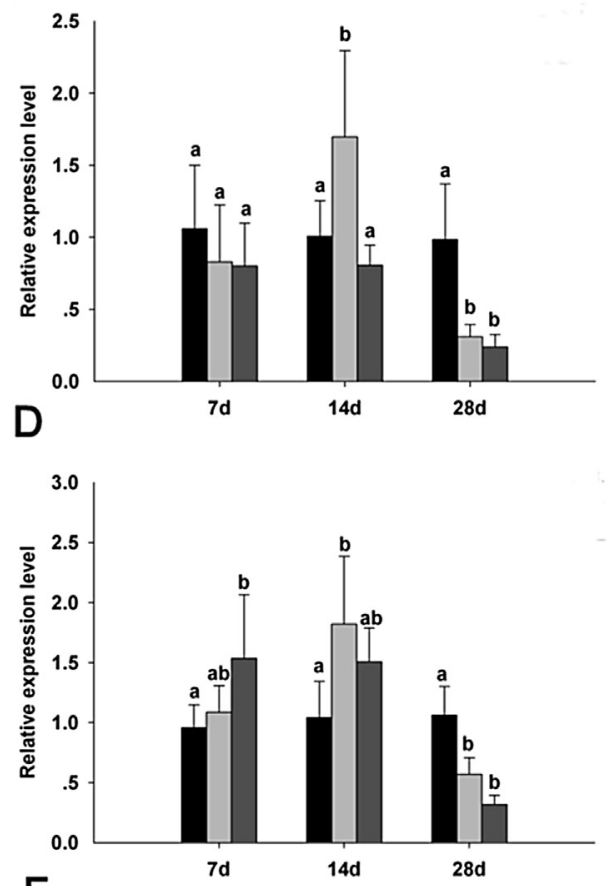

F

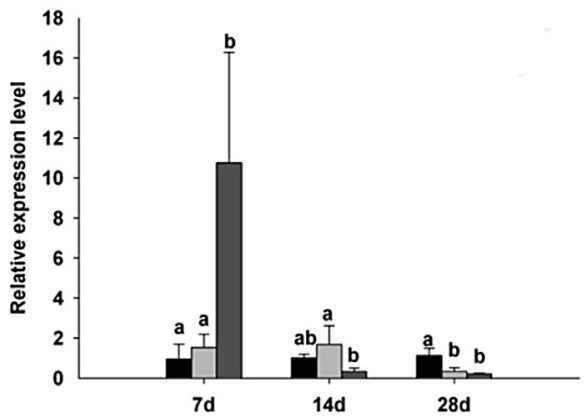

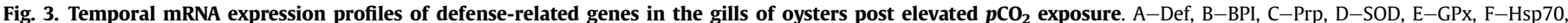

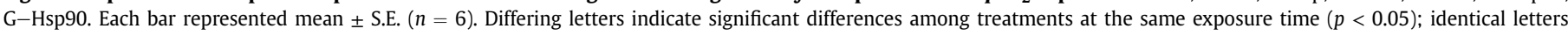
indicate no significant difference.

exposed to elevated $p \mathrm{CO}_{2}$ for 7 days. However, statistically significant increases in SOD (Fig. 2D) and GPx (Fig. 2E) mRNA levels have been observed, and mRNA expressions of Prp (Fig. 2C) and Hsp70 (Fig. 2F) were significantly inhibited under $p \mathrm{CO}_{2}$ exposure on Day 7. On Day 14 , elevated $p \mathrm{CO}_{2}$ exposure led to a statistically significant increase in mRNA levels of all examined genes with the exception of Def, the mRNA expression of which was significantly suppressed $(p<0.05)$. On Day 28, elevated $p \mathrm{CO}_{2}$ levels had no effect on Prp
(Fig. 2C) and GPx (Fig. 2E) mRNA levels, stimulated mRNA expression of Def (Fig. 2A), BPI (Fig. 2B) and Hsp70 (Fig. 2F), and led to a decrease in mRNA transcript levels of Prp (Fig. 2C) and Hsp90 (Fig. 2G).

In oyster gills, elevated $p \mathrm{CO}_{2}$ had no effect on the expression of BPI (Fig. 3B) and GPx (Fig. 3E) mRNA on Day 7. However, the transcripts of SOD (Fig. 3D), Hsp70 (Fig. 3F), and Hsp90 (Fig. 3G) were up-regulated, and Def (Fig. 3A) and Prp (Fig. 3C) transcripts 

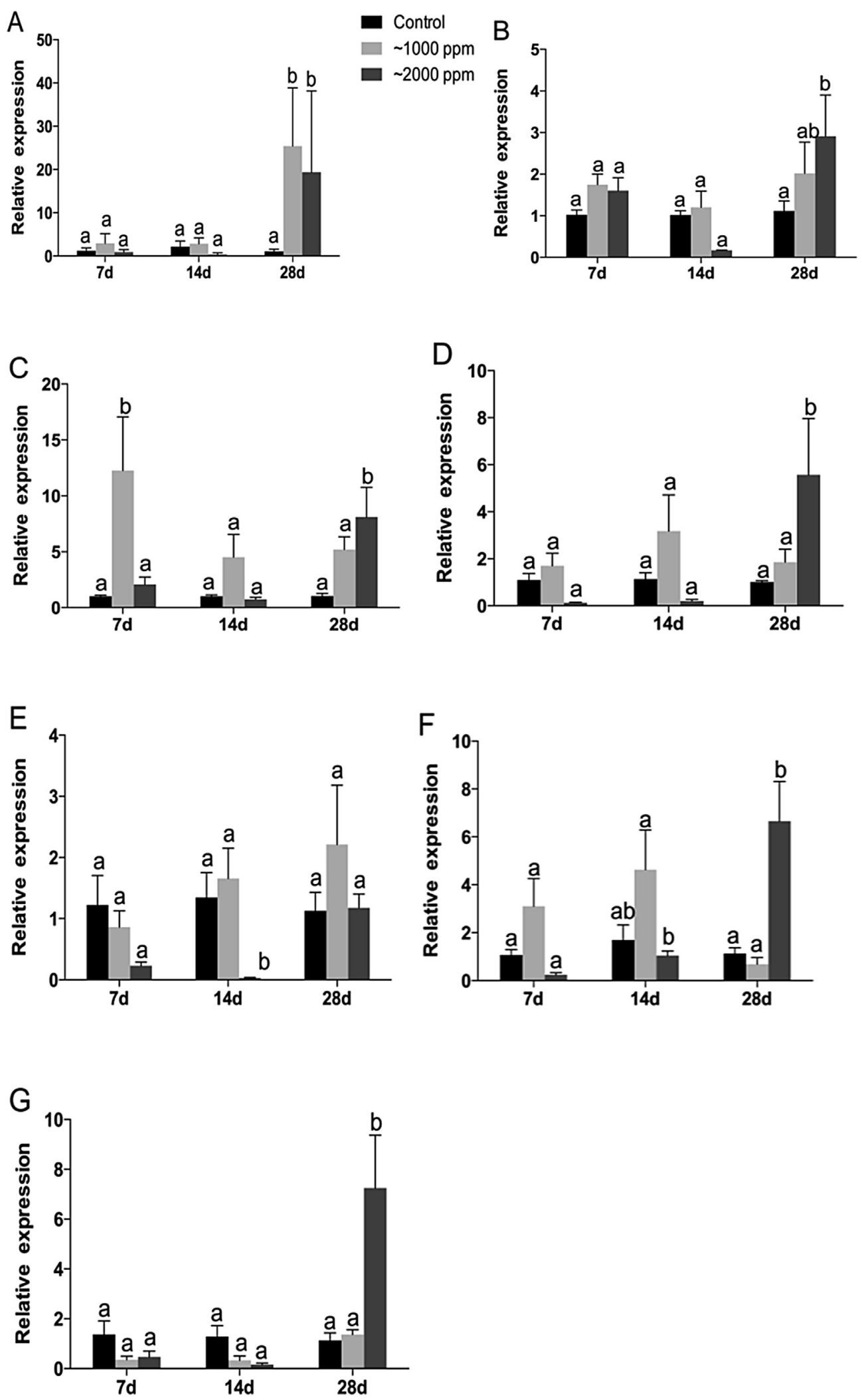

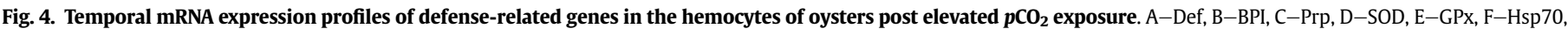

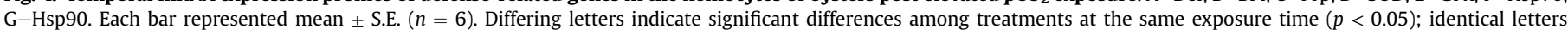
indicate no significant difference.

were down-regulated after exposed to elevated $\mathrm{pCO}_{2}$ for 7 days. On Day 14 , elevated $p \mathrm{CO}_{2}$ exposure led to a significant increase in the expression of BPI (Fig. 3B), Prp (Fig. 3C), SOD (Fig. 3D) and Hsp90
(Fig. 3G) transcripts, whereas Def (Fig. 3A), GPx (Fig. 3E) and Hsp70 (Fig. 3F) mRNA levels did not change after exposure to $p \mathrm{CO}_{2}$. The mRNA expressions of all these genes with the exception of Hsp90 

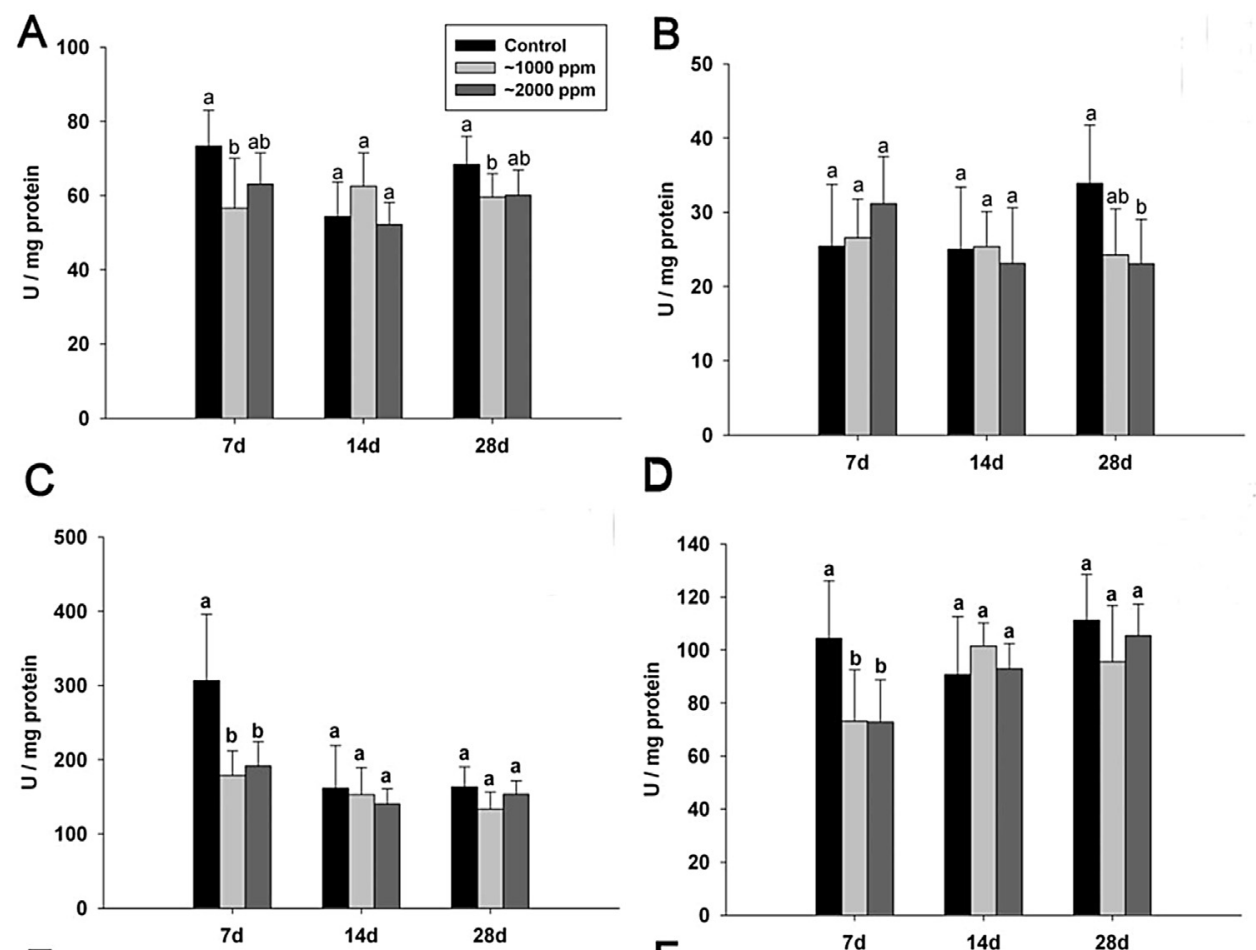

$E$
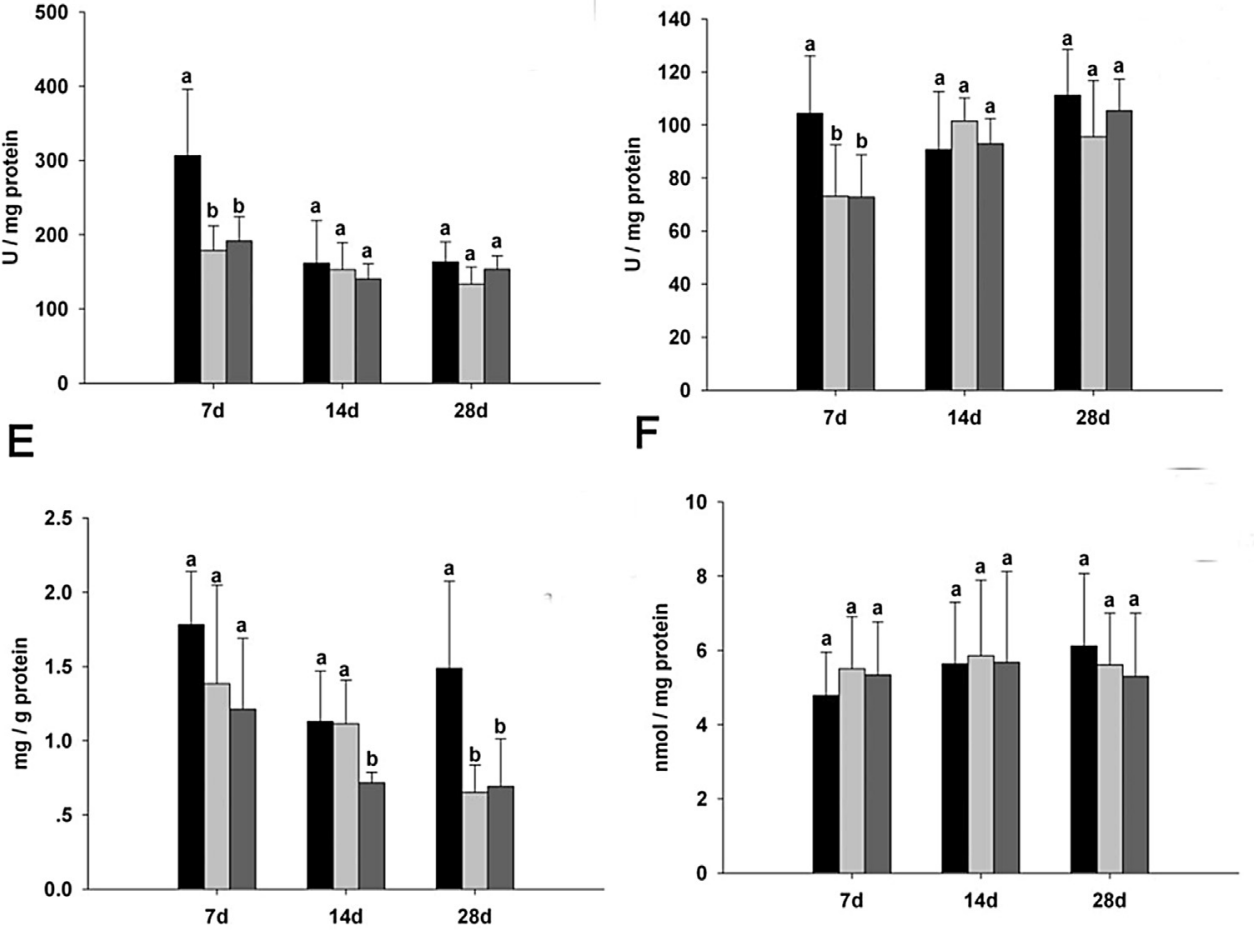

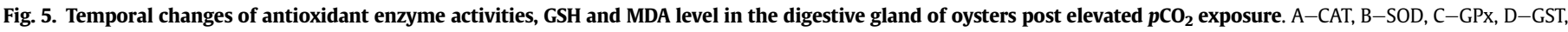

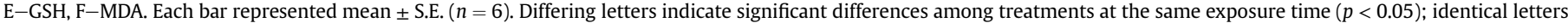
indicate no significant difference.

(Fig. 3G) were significantly suppressed by exposure to $p \mathrm{CO}_{2}$ at $\sim 2000$ ppm on Day $28(p<0.05)$.

In hemocytes, the mRNA expression of all the genes involved in immune response and apoptosis did not change significantly after exposed to elevated $p \mathrm{CO}_{2}$ for 7 and 14 days with the exception of Prp (Fig. 4C). However, the mRNA expressions of all these genes with the exception of Gpx (Fig. 4E) were significantly stimulated by exposure to $\mathrm{pCO}_{2}$ at $2000 \mathrm{ppm}$ on Day $28(p<0.05)$.

\subsection{Effects of $\mathrm{OA}$ on antioxidant enzyme activities, MDA and GSH} level in digestive gland and gills

In the digestive gland, the activities of CAT (Fig. 5A), GPx (Fig. 5C) and GST (Fig. 5D) decreased, whereas no significant change in the activities of SOD (Fig. 5B), GSH (Fig. 5E) and MDA level (Fig. 5F) was observed did after exposure to elevated $p \mathrm{CO}_{2}$ for 7 days. On Day 14, elevated $\mathrm{pCO}_{2}$ showed no significant effect on these enzymatic activities and the level of MDA. However, GSH content (Fig. 5E) was significantly decreased at the high $p \mathrm{CO}_{2}$ exposed group $(p<0.05)$.
On Day 28, both CAT (Fig. 5A) and SOD (Fig. 5B) activities were significantly suppressed in response to elevated $p \mathrm{CO}_{2}$, and $\mathrm{GSH}$ level (Fig. 5E) also decreased significantly $(p<0.05)$. Collectively, elevated $p \mathrm{CO}_{2}$ had an inhibitory effect on the antioxidant enzyme activities and decreased the GSH level in digestive gland.

In oyster gills, there was no significant effect on these enzymatic activities and the levels of GSH and MDA on Day 7 and Day 14 post elevated $\mathrm{pCO}_{2}$ exposure. On day 28, the CAT activities declined significantly after $p \mathrm{CO}_{2}$ exposure (Fig. $6 \mathrm{~A}$ ), while the MDA content (Fig. $6 \mathrm{~F})$ increased significantly $(p<0.05)$.

\section{Discussion}

A growing body of evidence has shown that OA poses a threat to ecologically and economically important mollusks. For example, OA was found to impact survival, development, physiology and growth of many marine mollusks [32]. Furthermore, OA exposure can also disturb the energy metabolism and regulation which might affect immune function in bivalves [14,18]. Recently, it has been found 

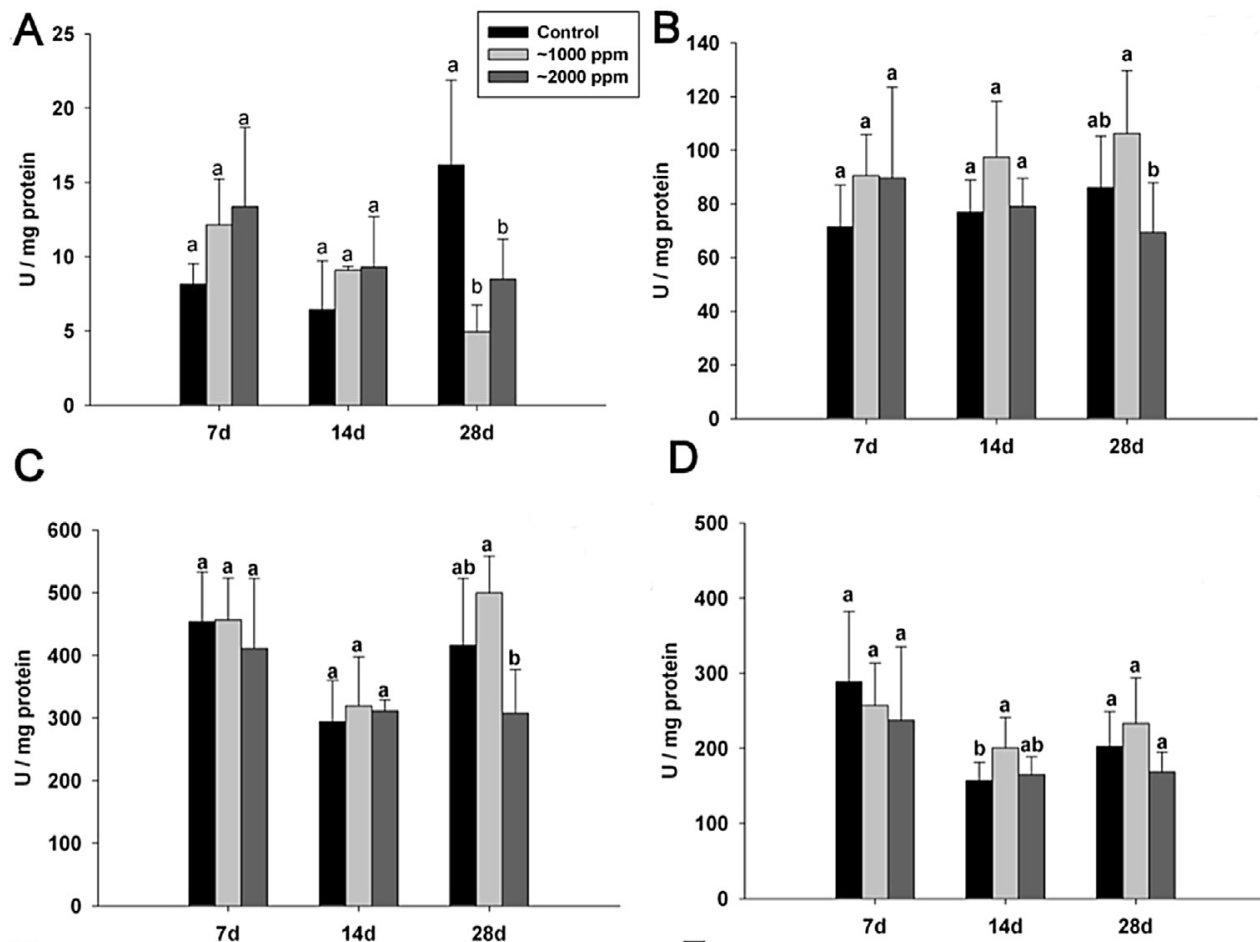

E
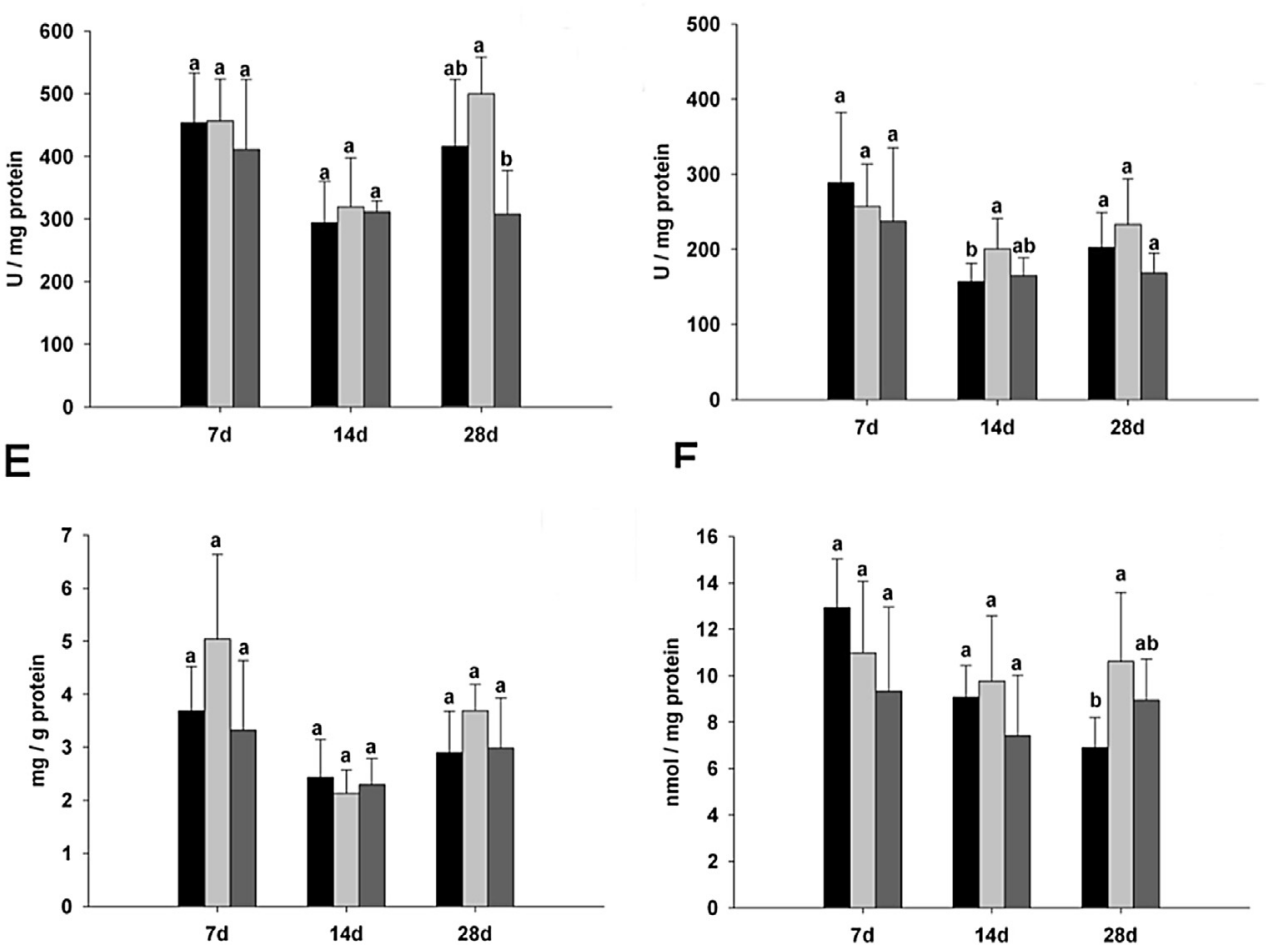

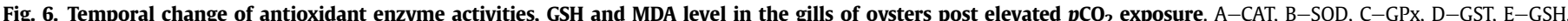

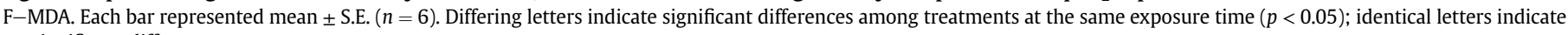
no significant difference.

that OA stress has the potential to promote pathogen development and survival, disease transmission and host susceptibility [33]. However, only few studies have investigated the immune responses of mollusks under OA stress so far [18,19,34].

Previous studies have demonstrated that phagocytic activity of hemocytes was affected by elevated $p \mathrm{CO}_{2}$ in several invertebrates. For example, inhibition of phagocytosis was observed in the mussel Mytilus edulis after exposure to elevated $p \mathrm{CO}_{2}$ for 32 days [18]. The phagocytic capacity of hemocytes was inhibited by $60 \%$ after a 4 month exposure to elevated $p \mathrm{CO}_{2}$ (hypercapnic seawater with a $\mathrm{pH}$ lowered by 0.4 units) in the crustacean Nephrops norvegicus [21]. Similarly, following long-term exposure for six months, the phagocytic capacity of coelomocytes reduced in Asterias rubens [20]. However, phagocytic function was not affected in M. edulis after a six month exposure to elevated $\mathrm{pCO}_{2}$ [33]. In the present study, elevated $p \mathrm{CO}_{2}$ did not have a significant effect on phagocytosis of hemocytes, indicating the phagocytic capacity was not impaired at present exposure level for 28 days. However, ROS production was significantly increased after $\sim 2000 \mathrm{ppm} \mathrm{pCO}_{2}$ exposure for 28 days, which suggested elevated $p \mathrm{CO}_{2}$ might cause oxidative stress in hemocytes. Similar result was also found in $M$. edulis, evidenced by an increase in oxidative burst after $\mathrm{OA}$ exposure [33]. In addition, apoptosis is also important for the functioning of the molluscan immune system [35]. However, little work has been performed on the impact of elevated $\mathrm{pCO}_{2}$ on apoptosis in bivalves. In the present study, a significant increase of hemocytes apoptosis rate was observed in oysters under high level of $\mathrm{pCO}_{2}$ exposure for 28 days. This phenomenon was primarily attributed to the failure of the antioxidant defense system induced by OA stress, which increased formation of intracellular ROS and then perhaps induced apoptosis [36]. In this study, the mRNA expression of the apoptosis genes (caspase 1 and caspase 3 ) in hemocytes were also found to be up-regulated under elevated $p \mathrm{CO}_{2}$ exposure for 28 days (Supplementary Fig. 1), which is similar in the coral Acropora millepora [37]. Nevertheless, OA exposure did not affect the apoptosis of hematopoietic tissue cell in the crustacean $N$. norvegicus [21]. Above all, OA had an impact on immune response of the Pacific oyster, which might be attributed to less energy spent on immune response [18].

After elevated $\mathrm{pCO}_{2}$ exposure, the transcription profiles of 
several genes involved in immune and defensive function showed different expression patterns in digestive gland. The expression of SOD and GPx transcripts increased significantly on Day 7 and Day 14 , indicating that $\mathrm{OA}$ perhaps induced oxidative stress in digestive gland firstly. However, as time progressed on, the expression of SOD transcript was inhibited on Day 28 perhaps due to the aggravation of oxidative stress. Similarly, the expression of GSTs (microsomal GST-2, GST-12) and glutathione peroxidase (GPx1) transcripts was also decreased in the sea urchin larvae under high $\mathrm{pCO}_{2}$ ( $1020 \mathrm{ppm})$ exposure [38]. In the present study, the transcripts of Def and Prp were down-regulated on Day 14 and Day 7, whereas they were up-regulated on Day 28 and Day 14 respectively. These results indicated that the mRNA expression pattern of these antimicrobial peptides in digestive gland varied depending on the exposure time. The mRNA expression profiles of molecular chaperones Hsp70 and Hsp90 also showed varied pattern, which might be ascribed to their multiple physiological functions involved in protein folding, and help to protect cells from stress [39].

In gills, OA induced the mRNA expression of BPI, Prp and Hsp90 on Day 14, suggesting OA might stimulate the immune function firstly. However, the transcripts Def, BPI, Prp, SOD, GPx and Hsp70 were significantly down-regulated on Day 28 , showing that $\mathrm{OA}$ inhibits the mRNA expression of immunity effectors and antioxidant enzymes in gills. In the coral A. millepora, a c-type lectin involved in innate immunity was down-regulated under elevated $p \mathrm{CO}_{2}$ (1010-1350 ppm) conditions [37]. In hemocytes of the Pacific oyster, the mRNA expressions of almost all tested genes were significantly stimulated after elevated $p \mathrm{CO}_{2}$ exposure ( $\left.2000 \mathrm{ppm}\right)$ for 28 days. These results indicated OA might cause oxidative stress on hemocytes to some extent. In the oyster Crassostrea virginica, mRNA expression of Hsp70 was suppressed in hemocytes after elevated $\mathrm{pCO}_{2}$ exposure ( $\left.2000 \mathrm{ppm}\right)$ for four weeks [34]. In sea urchin larvae, elevated $p \mathrm{CO}_{2}$ exposure $(\sim 1020 \mathrm{ppm})$ also resulted in down-regulation of genes involved in cellular stress response, such as Hsps (Hsp20, Hsp40 and Hsp70) and antioxidant enzymes [38].

The antioxidant defense system of living organisms can generally be categorized into enzymatic antioxidants, such as SOD, CAT, and GPx, and non-enzymatic antioxidants, such as GSH, vitamin E, ascorbate and urate [40]. The role of these antioxidant systems can be of great importance in response to environmental stress in aquatic animals [41]. Previous studies have demonstrated that OA exposure could generally cause oxidative stress in bivalve, sea urchin and coral $[37,38,42,43]$. In this study, the activities of antioxidant enzymes and GSH and MDA levels in gills did not change significantly on Day 7 and Day 14, suggesting this oyster could maintain its redox homeostasis in gills under elevated $p \mathrm{CO}_{2}$ exposure levels. However, CAT activity were significantly inhibited in gills after $\sim 2000 \mathrm{ppm} \mathrm{pCO}_{2}$ exposure for 28 days, which indicated the endogenous antioxidant defense mechanisms were overwhelmed by produced ROS [44]. In digestive gland, the activities of these antioxidant enzymes and GSH level generally deceased significantly when exposed in periods with different exposure level, indicating the occurrence of serious oxidative stress in this tissue. However, the effects of OA on the physiological response of mollusks are variable among species and even within the same species [32]. In $C$. virginica, SOD expression was up-regulated in the mantle tissue of oysters under elevated $\mathrm{pCO}_{2}$ condition ( $\mathrm{pH7.5)}$ [42]. In the clam Chamelea gallina and the mussel Mytilus galloprovincialis, OA stress also generally caused increases in antioxidant enzyme activities after exposure for 7 days [43]. In other marine invertebrate, the mRNA expression of oxidoreductase (CAT, FAD linked oxidase and selenoprotein) was also up-regulated in high $\mathrm{pCO}_{2}$ treated coral at day 28 [37]. However, in the copepod Centropages tenuiremis exposed to elevated $\mathrm{pCO}_{2}$, significant decreases in SOD activity and GSH content were observed on day 1 [45].
Overall, the present study has demonstrated that elevated $p \mathrm{CO}_{2}$ has a significant impact on the immune systems of oyster, and may constitute a potential threat to increased susceptibility of bivalves to diseases. Long-term studies are required to assess possible adaptation of the immune system during continuous acidification stress. Furthermore, the synergistic effects of OA with other environmental factors, such as temperature and hypoxia also need further investigation.

\section{Acknowledgments}

This research was supported by grants from the National Natural Science Foundation of China (No. 31172388, 41206120), the Key Research Program of the Chinese Academy of Sciences (Grant No. KZZD-EW-14), the Strategic Priority Research Program of the Chinese Academy of Sciences (XDA11020405) and Zhejiang Provincial Top Key Discipline of Aquaculture Open Foundation (No. XKZSC1402).

\section{Appendix A. Supplementary data}

Supplementary data related to this article can be found at http:// dx.doi.org/10.1016/j.fsi.2015.12.025.

\section{References}

[1] C.L. Sabine, R.A. Feely, N. Gruber, R.M. Key, K. Lee, J.L. Bullister, et al., The oceanic sink for anthropogenic $\mathrm{CO}_{2}$, Science 305 (2004) 367-371.

[2] G.A. Meehl, T.F. Stocker, W.D. Collins, P. Friedlingstein, A.T. Gaye, A. Kitoh, et al., Global climate projections, in: S. Solomon, D. Qin, M. Manning, Z. Chen, et al. (Eds.), Climate Change 2007: the Physical Science Basis. Contribution of Working Group I to the Fourth Assessment Report of the Inter -governmental Panel on Climate Change, Cambridge University Press, Cambridge, 2007, pp. 749-844.

[3] J.B. Smith, S.H. Schneider, M. Oppenheimer, G.W. Yohe, W. Hare, M.D. Mastrandrea, et al., Assessing dangerous climate change through an update of the Intergovernmental Panel on Climate Change (IPCC) "reasons for concern", Proc. Natl. Acad. Sci. U. S. A. 106 (11) (2009) 4133-4137.

[4] J.C. Orr, V.J. Fabry, O. Aumont, L. Bopp, S.C. Doney, R.A. Feely, et al., Anthropogenic ocean acidification over the twenty-first century and its impact on calcifying organisms, Nature 437 (7059) (2005) 681-686.

[5] S.C. Doney, V.J. Fabry, R.A. Feely, J.A. Kleypas, Ocean acidification: the other $\mathrm{CO}_{2}$ problem, Annu. Rev. Mar. Sci. 1 (2009) 169-192.

[6] S.C. Doney, M. Ruckelshaus, J.E. Duffy, J.P. Barry, F. Chan, C.A. English, H.M. Galindo, J.M. Grebmeier, A.B. Hollowed, N. Knowlton, J. Polovina, N.N. Rabalais, W.J. Sydeman, L.D. Talley, Climate change impacts on marine ecosystems, Annu. Rev. Mar. Sci. 4 (2012) 11-37.

[7] G.E. Hofmann, J.P. Barry, P.J. Edmunds, R.D. Gates, D.A. Hutchins, T. Klinger, et al., The effect of ocean acidification on calcifying organisms in marine ecosystems: an organism-to-ecosystem perspective, Annu. Rev. Ecol. Evol. S 41 (2010) 127-147.

[8] H. Kurihara, S. Kato, A. Ishimatsu, Effects of increased seawater $p \mathrm{CO}_{2}$ on early development of the oyster Crassostrea gigas, Aquat. Biol. 1 (2007) 91-98.

[9] $\mathrm{H}$. Kurihara, Effects of $\mathrm{CO}_{2}$-driven ocean acidification on the early developmental stages of invertebrates, Mar. Ecol. Prog. Ser. 373 (2008) 275-284.

[10] S.C. Talmage, C.J. Gobler, Effects of past, present, and future ocean carbon dioxide concentrations on the growth and survival of larval shellfish, Proc. Natl. Acad. Sci. U. S. A. 107 (2010) 17246-17251.

[11] V. Amaral, H.N. Cabral, M.J. Bishop, Moderate acidification affects growth but not survival of 6-month-old oysters, Aquat. Ecol. 46 (2012) 119-127.

[12] L.M. Parker, P.M. Ross, W.A. O'Connor, L. Borysko, D.A. Raftos, H.O. Portner Adult exposure influences offspring response to ocean acidification in oysters, Glob. Change Biol. 18 (2012) 82-92.

[13] F. Melzner, P. Stange, K. Trübenbach, J. Thomsen, I. Casties, U. Panknin, et al. Food supply and seawater $\mathrm{pCO}_{2}$ impact calcification and internal shell dissolution in the blue mussel Mytilus edulis, PLoS One 6 (2011) e24223.

[14] G. Lannig, S. Eilers, H.O. Portner, I.M. Sokolova, C. Bock, Impact of ocean acidification on energy metabolism of oyster, Crassostrea gigas - changes in metabolic pathways and thermal response, Mar. Drugs 8 (2010) 2318-2339.

[15] R. Bibby, P. Cleall-Harding, S. Rundle, S. Widdicombe, J. Spicer, Ocean acidification disrupts induced defences in the intertidal gastropod Littorina littorea, Biol. Lett. 3 (2007) 699-701.

[16] E. Sanford, B. Gaylord, A. Hettinger, E.A. Lenz, K. Meyer, T.M. Hill, Ocean acidification increases the vulnerability of native oysters to predation by invasive snails, P. Roy. Soc. B 281 (2014) 20132681.

[17] S. Dupont, O. Ortega-Martinez, M. Thorndyke, Impact of near-future ocean acidification on echinoderms, Ecotoxicology 19 (2010) 449-462. 
[18] R. Bibby, S. Widdicombe, H. Parry, J. Spicer, R. Pipe, Effects of ocean acidification on the immune response of the blue mussel Mytilus edulis, Aquat. Biol. 2 (2008) 67-74.

[19] V. Matozzo, A. Chinellato, M. Munari, L. Finos, M. Bressan, M.G. Marin, First evidence of immunomodulation in bivalves under seawater acidification and increased temperature, PLoS One 7 (3) (2012) e33820.

[20] B. Hernroth, S. Baden, M. Thorndyke, S. Dupont, Immune suppression of the echinoderm Asterias rubens (L.) following long-term ocean acidification, Aquat. Toxicol. 103 (2011) 222-224.

[21] B. Hernroth, H.N. Sköld, K. Wiklander, F. Jutfelt, S. Baden, Simulated change causes immune suppression and protein damage in the crustacean Nephrops norvegicus, Fish. Shellfish Immunol. 33 (2012) 1095-1101.

[22] G. Zhang, X. Fang, X. Guo, L. Li, R. Luo, F. Xu, et al., The oyster genome reveals stress adaptation and complexity of shell formation, Nature 490 (2012) 49-54.

[23] R. Dineshram, V. Thiyagarajan, A. Lane, Z.N. Yu, X. Shu, P.T.Y. Leung, Elevated $\mathrm{CO}_{2}$ alters larval proteome and its phosphorylation status in the commercial oyster, Crassostrea hongkongensis, Mar. Biol. 160 (2013) 2189-2205.

[24] A.W. Miller, A.C. Reynolds, C. Sobrino, G.F. Riedel, Shellfish face uncertain future in high $\mathrm{CO}_{2}$ world: influence of acidification on oyster larvae calcification and growth in estuaries, PLoS One 4 (5) (2009) e5661.

[25] C. Haraldsson, L.G. Anderson, M. Hassellöv, S. Hulth, K. Olsson, Rapid, highprecision potentiometric titration of alkalinity in ocean and sediment pore waters, Deep Sea Res. Part I 44 (1997) 2031-2044.

[26] E. Lewis, D.W.R. Wallace, Program Developed for $\mathrm{CO}_{2}$ System Calculations ORNL/CDIAC-105 Carbon Dioxide Information Analysis Center, Oak Ridge National Laboratory, US Department of Energy, Oak Ridge, Tennessee, 1998.

[27] F.J. Millero, T.B. Graham, F. Huang, H. Bustos-Serrano, D. Pierrot, Dissociation constants of carbonic acid in seawater as a function of salinity and temperature, Mar. Chem. 100 (2006) 80-94.

[28] A.G. Dickson, Standard potential of the reaction: $\mathrm{AgCl}(\mathrm{s})+1 / 2 \mathrm{H} 2(\mathrm{~g})=\mathrm{Ag}(\mathrm{s})+$ $\mathrm{HCl}(\mathrm{aq})$, and the standard acidity constant of the ion HSO4- in synthetic seawater from 273.15 to 318.15 K, J. Chem. Thermodyn. 22 (1990) 113-127.

[29] I.M. Sokolova, S. Evans, F.M. Hughes, Cadmium-induced apoptosis in oyste hemocytes involves disturbance of cellular energy balance but no mitochondrial permeability transition, J. Exp. Biol. 207 (19) (2004) 3369-3380.

[30] K.J. Livak, T.D. Schmittgen, Analysis of relative gene expression data using real-time quantitative PCR and the 2(-Delta DeltaC(T)) method, Methods 25 (2001) 402-408.

[31] H. Ringwood, D.E. Conners, C.J. Keppler, A.A. DiNovo, Biomarker studies with juvenile oysters (Crassostrea virginica) deployed in situ, Biomarkers 4 (1999) 400-415.
[32] F. Gazeau, L. Parker, S. Comeau, J.P. Gattuso, W. O'Connor, S. Martin, H.O. Pörtner, P. Ross, Impacts of ocean acidification on marine shelled molluscs, Mar. Biol. 160 (8) (2013) 2207-2245.

[33] C.L. Mackenzie, S.A. Lynch, S.C. Culloty, S.K. Malham, Future oceanic warming and acidification alter immune response and disease status in a commercial shellfish species, Mytilus edulis L. PLoS One 9 (6) (2014) e99712.

[34] A.V. Ivanina, C. Hawkins, I.M. Sokolova, Immunomodulation by the interactive effects of cadmium and hypercapnia in marine bivalves Crassostrea virginica and Mercenaria mercenaria, Fish. Shellfish Immunol. 37 (2) (2014) 299-312.

[35] I.M. Sokolova, Apoptosis in molluscan immune defense, Invertebr. Surviv. J. 6 (2009) 49-58.

[36] J.F. Turrens, Mitochondrial formation of reactive oxygen species, J. Physiol. 552 (2003) 335-344.

[37] P. Kaniewska, P.R. Campbell, D.I. Kline, M. Rodriguez-Lanetty, D.J. Miller, S. Dove, et al., Major cellular and physiological impacts of ocean acidification on a reef building coral, PLoS One 7 (4) (2012) e34659.

[38] A.E. Todgham, G.E. Hofmann, Transcriptomic response of sea urchin larvae Strongylocentrotus purpuratus to $\mathrm{CO}_{2}$-driven seawater acidification, J. Exp. Biol. 212 (2012) 2579-2594.

[39] M. Sherman, A.L. Goldberg, Cellular defenses against unfolded proteins: a cell biologist thinks about neurodegenerative diseases, Neuron 29 (2001) 15-32.

[40] L.L. de Zwart, J.H.N. Meerman, J.N.M. Commandeur, N.P.E. Vermeulen, Biomarkers of free radical damage. Applications in experimental animals and in humans, Free Radic. Biol. Med. 26 (1999) 202-226.

[41] A. Valavanidis, T. Vlahogianni, M. Dassenakis, M. Scoullos, Molecular biomarkers of oxidative stress in aquatic organisms in relation to toxic environmental pollutants, Ecotoxicol. Environ. Saf. 64 (2006) 178-189.

[42] L. Tomanek, M.J. Zuzow, A.V. Ivanina, E. Beniash, I.M. Sokolova, Proteomic response to elevated $\mathrm{PCO}_{2}$ level in eastern oysters, Crassostrea virginica: evidence for oxidative stress, J. Exp. Biol. 214 (2011) 1836-1844.

[43] V. Matozzo, A. Chinellato, M. Munari, M. Bressan, M.G. Marin, Can the combination of decreased $\mathrm{pH}$ and increased temperature values induce oxidative stress in the clam Chamelea gallina and the mussel Mytilus galloprovincialis? Mar. Pollut. Bull. 72 (1) (2013) 34-40.

[44] A.A. Soldatov, O.L. Gostyukhina, I.V. Golovina, Antioxidant enzyme complex of tissues of the bivalve Mytilus galloprovincialis Lam. under normal and oxidative-stress conditions: a review, Appl. Biochem. Microbiol. 43 (2007) $556-562$.

[45] D. Zhang, S. Li, G. Wang, D. Guo, K. Xing, S. Zhang, Biochemical responses of the copepod Centropages tenuiremis to $\mathrm{CO}_{2}$-driven acidified seawater, Water Sci. Technol. 65 (1) (2012) 30-37. 